\title{
Reflective Practice and Teaching Creativity of Indonesian ELT Practitioners within the Postmethod Paradigm
}

\author{
Muhamad Ahsanu \\ \{ahsanu.muhamad@yahoo.com\} \\ Universitas Jenderal Soedirman \\ Jl. Profesor DR. HR Boenyamin No.708, Dukuhbandong, Grendeng, Kec. Purwokerto Utara, \\ Kabupaten Banyumas, Jawa Tengah 53122, Indonesia
}

\begin{abstract}
This article discusses the interconnection between reflective practices, teaching creativity under post-method paradigm in the practice of English language teaching (ELT) practitioners in Indonesian context. It aims to explore the extent to which Indonesian ELT practitioners are engaged in the post-method paradigm in terms of its pedagogy of particularity, practicality and possibility through reflectivity and creativity. This research takes a qualitative approach, collecting the data using observation, interview and documents, and analysing the data using content analysis. The findings suggest that qualitatively Indonesian ELT practitioners are both reflective and creative in their teaching; their practice is not impulsive and repetitive; they evaluate their own teaching and reflect on what is happening and what happened in their class; they also solve classroom problems creatively by particularizing their teaching approach and technique; and they are not dependent on a certain prescriptive method, but they use and develop their own way of teaching.
\end{abstract}

Keywords: PMC, PMP, RP, TC, ELT, Indonesian context

\section{Introduction}

This inquiry is motivated by the post-method paradigm with its core principles entailing aspect of practice (pedagogy of practicality), aspect of context (pedagogy of particularity), and aspect of empowerment (pedagogy of possibility) [40] (p. 69). These aspects, as Kumaravadivelu hinted, seem to empower the teachers to reflect on their own potential in order to creatively innovate their teaching-learning praxis. Post-method pedagogy (PMP) is the anti-thesis of method-based pedagogy, where searching for a best method is no longer the norm in language teaching, but what really matters is the need for teachers to learn "to operate with some personal conceptualization of how their teaching leads to desired learning" [51] (p. 172), called teachers' "sense of plausibility" (p. 175). Prabhu argues that how methodological principles are implemented in practice depends on teachers' beliefs and their subjective understandings of teaching in their own particular contexts. Instead of looking for best methods, which is a useless effort because it is not available, it is considerably better to pave the way for teachers to be more autonomous and self-empowered in their teaching. Hall [27] notes that a consequence of this sense of plausibility is that methodological principles may be realized in different ways by different teachers where the elements of different methods can be 
blended. In that way, teachers should derive the crucial learning and teaching decisions about what might work and might not work in their classroom based on their own 'sense of plausibility or principled pragmatism' [37] (p. 34).

With a good understanding of this principled pragmatism, teachers can focus on shaping and reshaping their classroom learning based on the result of self-observation, self-analysis, and self-evaluation [38]. Hence, teachers' sense of plausibility which is teachers' "subjective understanding of the teaching they do" [51] (p. 172) plays a crucial role in the teaching activity. The real challenge facing the profession is neither how to design a new method [49] nor to find an alternative method [34], [35], [37] but assist teachers to activate their sense of plausibility so that they can teach on the basis of principled pragmatisms, that is being able to recognize what can and what cannot function in their classroom. This alternative-to-method paradigm is what we know as Post-method pedagogy (PMP), the theoretical framework of this research. In fact, pedagogical thoughtfulness, as Kumaravadivelu [35] notes, simultaneously feeds and is fed by reflective capabilities, of teachers that enable them to understand and identify problems, [34] analyse and assess information, consider and evaluate alternatives and then choose the best available alternative, which is subjected to further critical appraisal (p. 541). PMP as a way forward was triggered by post method condition (PMC). It essentially signifies teacher autonomy recognizing the teachers' potential to know not only how to teach but also know how to act autonomously within the academic and administrative constraints imposed by institutions, curricula, and textbooks (p. 30). This indicates two important elements teachers should equip themselves with in order to be able to actuate PMP functionally: being reflective and being creative pedagogues. Through PMC, accordingly, teachers become more critical, more independent, more empowered and more alert to identify and implement their hands-on teaching framework. That means the teachers are liberated to empower themselves, to theorize their practice and to practice their theory of teaching, and to cultivate the particularity, the practicality and the possibility in their own specifically contextualized classrooms. This Word document can be used as a template for journal. This Word document can be used as a template for journal. This Word document can be used as a template for journal. This Word document can be used as a template for journal. This Word document can be used as a template for journal

\section{Theotitical Framework}

The main text should be written using Times New Roman, 10pt, fully justified. Italics can be used for emphasis and bold typeset should be avoided. This study was designed on the framework of theoretical analysis stemming from post-method condition (PMC), resulting in post-method pedagogy (PMP), reflective practice (RP) and teaching creativity (TC) as shown in Fig. 1 below.

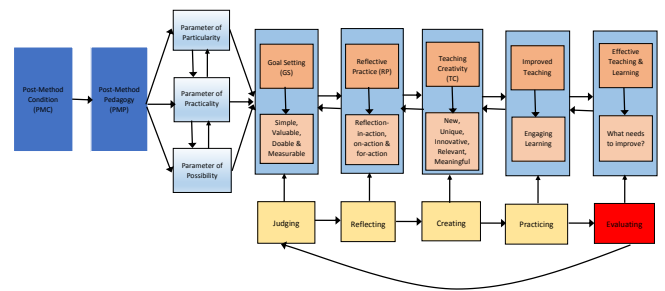

Fig. 1. A framework of analysis 
The framework is an explorative study is based on the paradigm shift from method-based into post-method-based pedagogy [34], [33], [35], [37], from transmission-based teaching into transformation-based teaching [30], self-learning grounded in their practice of classroom teaching [32]. This framework is viewed from the practice of RP and TC (presumed manifestation of PMP) within Indonesian context. In other words, RP and TC are the core of PMP. This is because, according to Richards [52], creative teachers seem to possess critical reflectivity, by which they review and reflect on their own practice, seek to expand new ideas and practices that they can apply in their own classrooms. The incoming PMP, that emerged owing to the dissatisfaction the methods-oriented teaching [35] marks a re-empowering position of teachers since it is the teacher who should make the crucial learning and teaching decisions about what works or does not work in his or her classroom based on his or her sense of plausibility [51].

\subsection{Postmethod condition (PMC)}

The direction in ELT has been shifted from method-oriented to post-method-oriented, marked by the emergence of so-called post-method condition (PMC) [34]. In the lens of $\mathrm{PMC}$, it is often labelled by leaving methods-only arguments to find effective strategies to teach in the most appropriate and effective way while taking into account the teachers' views and roles in preparing and teaching language materials [30]. PMC is advocated as a manifestation of a renewed awareness. It is an awareness to refigure the relationship between the theorizers and the practitioners of method [34]. It is the awareness that drives the local classroom practitioners to stop adhering faithfully to the centre formulated theory on how to enact teaching in their classrooms. This renewed awareness [34] 'empowers practitioners to construct classroom-oriented theories of practice and enables practitioners to generate location-specific, classroom-oriented innovative practices' (p. 29).

Similar stance is voiced by Canagarajah [8] who mentions that 'the orientation that there is no "best method" that assures successful learning can empower local teachers to focus on the learning strategies that work for their own students in the light of the purposes and objectives that define their teaching' [8]. In other words, the PMC [37] enables and empowers teachers to theorize from their practice and practice what they have theorized and to focus on shaping and reshaping their classroom learning based on the result of self-observation, selfanalysis, and self-evaluation (p. 30). This implies that PMC promotes the ability of teachers to know how to develop a reflective approach to their own teaching, how to analyse and evaluate their own teaching practice, how to customize their lesson, adjust their lesson plan, initiate necessary changes in their classroom, and how to assess the effects of such changes.

\subsection{Post-method pedagogy (PMP)}

The realization of the PMC is in the form of post-method pedagogy (PMP). This suggests that the norm in language teaching is no longer about searching for a best method, yet what really matters is the need for teachers to learn 'to operate with some personal conceptualization of how their teaching leads to desired learning' [51] (p. 172). This conceptualization is what Prabhu calls 'sense of plausibility' (p. 175). According to Kumaravadivelu [35], post-method teachers should construct their personal theories by testing, interpreting, and judging the usefulness of professional theories which can potentially create a wider space for them to function fruitfully as reflective as well creative practitioners. This implies that they set themselves free from any imposing and limiting external, 
prescriptive theory of teaching. The PMP encapsulates a reflective model of teaching in the form of observational-reflective techniques for teachers [38]. Such reflectivity potentially mediates creativity in language teaching. Richards [52] sounds this by stating that 'creative teachers seem to possess critical reflectivity, by which they review and reflect on their own practice, seek to expand new ideas and practices that they can apply in their own classrooms' (p. 30).

In reality, teachers make a whole series of decisions about teaching based on their own educational experiences, their personalities, their particular institutional, social, cultural and political circumstances, their understanding of their particular students' collective and individual needs, and so on [65]. PMP [37] refers to a grounded "process in which local language teachers, using their professional and personal knowledge take the initiative to construct a pedagogy that is sensitive to their local needs, wants, and situation" (p.545). PMP theoretically is made up of threefold pedagogical parameters knows as PPP: pedagogies of particularity, practicality and possibility [35], [38], [39]. Technically, the theory of PMP is about conducting locality-wise teaching, based on both comprehensive students' needs assessment to ensure what a teacher provides in the classroom is what precisely students want to learn and teachers' theoretical, practical and experiential knowledge and skills of teaching. In PMP, teachers are supposed to theorize from their practice and practice their own theory [37]. In addition to teacher empowerment, in PMP students are empowered through understanding the uniqueness and all differences (social, cultural, economic, etc.) they bring to the classroom, by which they are enabled to learn. So, PMP is focused on the aspects of context, practice and empowerment. In PMP, there is a three-dimensional system consisting of three pedagogic system parameters: particularity, practicality and possibility (PPP).

\subsubsection{Particularity}

This parameter is based on the firm belief that all pedagogy is local and particular. This suggests that 'a language teaching program must be sensitive to a particular group of teachers teaching a particular group of learners pursuing a particular set of goals within a particular institutional context embedded in a particular socio-cultural milieu' [35] (p. 538). Such a pedagogy is responsive to and responsible for local individual, institutional, social and cultural contexts in which learning and teaching take place [37]. This particularity seeks to facilitate the advancement of context-sensitive, location specific pedagogy that is based on a true understanding of local linguistic, sociocultural, and political particularities [35]. This critical awareness [40] starts with practicing teachers assessing local needs, observing their teaching acts, evaluating their outcomes, identifying problems, finding solutions, and trying them out to see once again what works and what doesn't (p. 69). The iterative flow of activities entailing observation, reflection and action which becomes a prerequisite for the development of context-sensitive pedagogic knowledge [35]. This suggests that every student, every lesson, and every class are distinctive and unique so each needs different treatment.

\subsubsection{Practicality}

The aspects of practicality is based on a proposition that 'no theory of practice can be useful and usable unless it is generated through practice' [35] (p. 541), where a language teacher assumes the role of autonomous theorizer rather than a mere 'consumer' of externally prescribed theories [37]. This pedagogy of practicality seeks to encourage and enable teachers themselves to theorize from their practice and practice what they theorize [35]. Kumaravadivelu points out that 'a teacher's personal theory involves keeping one's eyes and ears and mind open in the classroom to see what works and what doesn't, with what group(s) 
of learners, for what reasons, and assessing what changes are necessary to make instruction achieve its desired goals. It involves continual reflection and action' [36] (p. 39). The central message in this pedagogy is the empowerment of teachers to create their own unique theory of practice. Sensibly, 'theory and practice mutually inform, and together constitute a dialectical praxis' [35] (p. 540). Pedagogy of practicality, in van Manen's (1991) stance, is the result of pedagogical thoughtfulness. It implies that a theory of practice is conceived when there is a union of action and thought. Practically, practicality means you do what you think you can do and your students can learn from what you do comfortably and meaningfully.

\subsubsection{Possibility}

The parameter of possibility is derived from Freirean critical pedagogy that seeks to empower classroom participants so that they can critically reflect on the social and historical conditions which create the cultural forms and interested knowledge that give meaning to the lives of teachers and learners [36]. The key word empower [37] here implies at least two facets: 1) it facilitates the possibility of power for both teachers and learners to do something related and relevant with their state of being in their society attributing to their teaching and learning; 2) it makes both teachers and learners more confident in the acts of teaching and learning. The pedagogy of possibility is designed to empower participants and point to 'the need to develop theories, forms of knowledge, and social practices that work with the experiences that people bring to the pedagogical setting' [35] (p. 543). The crux of the matter is that both teachers and learners are in the position of mutuality not resistance. They need one another coming to the common term: learning and sharing together.

\subsection{Reflective practice (RP)}

Being able to learn from what happen in the past helps teachers to reconstruct and redesign their future teaching that can lead to a success in the classroom. This depends largely on the personal investment of the teacher, how this investment is enacted interpersonally and socially, and how it establishes the classroom as a safe and engaging zone for language learning [31]. This investment is then called RP. By reflecting, ELT practitioners authorize themselves to do self-appraisal, analysing the spots where they have satisfactorily performed and to be maintained and developed and the critical areas where further attention and effort need to be harboured. A kind of self-empowering through which a pedagogical change in the form of an informed practice can take place. This line of thought is based on the belief that the reflective practitioner is constantly changing, both in terms of their understanding of the factors which shape classroom learning, their planning for lessons and learning activities, and their classroom teaching [32].

\subsubsection{Dimensions of RP}

RP holds an essential dimension of effective teaching as it leads teachers to subject themselves to a process of self-observation or self-evaluation. They have the agency and they have their independency. When these two basic requirements are at hand, teachers are situationally empowered to do reflection. Baldez et al. [3] note that reflective teaching is a process of self-actualization which, in turn, is a product of the mental work in making sense of meaning [3]. This denotes that teachers who undergo reflective teaching become more conscious about their work in the classroom and beyond [20]. According to York-Barr et al. [71], RP can nurture teaching practitioners to grow and expand their repertoire of effective instructional practices. In doing so, teaching practitioners are striving to move from so-called a 
culture of doing or practicing to a culture of thinking and learning with doing. This kind of culture (thinking, learning with doing) is what is referred to as the praxis of ELT. Hence, as Farrell [22] suggests that the interest in reflective teaching is principally meant for the empowerment of teachers. Dewey [17] recommended teachers to take reflective action that involves 'active, persistent, and careful consideration of any belief or supposed form of knowledge in light of the grounds that support it and the further consequences to which it leads' (p. 9). In this view, Dewey sees reflective action as a sort of a teacher-self-initiated activity involving willingness to engage in constant self-appraisal and professional development.

\subsubsection{Types of RP}

In addition to the dimensions of RP mentioned above, RP is also classified into, in this respect, three main types, which are based upon a more intuitional and practical notion as proposed by Donald Schon. According to Schon [58], [59], RP can be divided into two types: reflection-in-action and reflection-on-action. Schon spells out that reflection-in-action refers to the process of observing our thinking and action as they are occurring, in order to make adjustments in the moment. Meanwhile, reflection-on-action denotes the process of looking back on and learning from experience or action in order to affect future action. Farrell [21] expanded the previous two kinds of action into reflection-for-action. This third action can mean two things [21]. First, we do reflection because we want to understand what we have done better, know more about it, change or improve it. Secondly, this reflection is about planning to take some positive steps to do something with what we have learnt. Hence, RP is an action or performance: it is teaching which is shaped and informed by the outcomes of reflection [30], of which the goal is to derive improvement in the practice of teaching for the sheer benefits of students' learning. The gist of RP is when thinking and action are complimentary in the practice of teaching, which creates a praxis in which 'reflection and action truly transform reality' [24] (p. 73).

\subsection{Teaching creativity (TC)}

Carter [9] remarks that creativity is now considered 'not simply a property of exceptional people but an exceptional property of all people' (p. 13). In this light, a "democratization" of the concept of creativity [47] has been promoted, or a sort of "soft" version of creativity that can inclusively embrace any man of ideas. In other words, all teachers have the potential to be creative in a certain unique way as the creativity of every individual has its own context and dimension. Boden [4] mentions that creativity has three elements (p. 2). The first element of creativity is newness, that is 'coming up with a surprising and valuable idea that is new to the individual concerned. The second element is the notion of "surprising idea". She argues that we may be surprised by an idea because it is unlikely, unexpected or even impossible. The last element is the question of what makes an idea valuable. Upon this perspective, a new and surprising idea could be considered valuable if it can be used strategically to achieve a dynamic interaction in the classroom.

\subsubsection{Dimensions of TC}

Creativity is usually described as having a number of different dimensions. However, in this paper the idea of creativity taken into account is the everyday creativity or 'little c creativity' [14] (p. 45), as 'the creative potential of all individuals' [43] (p. 24). This suggests that creativity is unique potential and quality shared by all people and therefore all ELT 
practitioners are creative individuals. Creativity is usually described as having a number of different dimensions. Richards and Cotterall [53] exert that teachers are often required to think creatively or "out of the box", a kind of improvisation. Sawyer [56] mentions that creative teaching is an 'improvisational performance' (p. 13). Therefore, according to Richards [52], fostering creative teaching is becoming even more crucial-albeit more challenging-as teaching environments become "increasingly standardized," (p. 17) with set curricula and materials and test-driven teaching, and increasingly pressured, with teachers rarely given enough time to develop more creative ways of working.On this basis, Jones [28] (p. 477) is right to say that creativity is to a large extent a matter of finding our way around constraints or limitations placed on us by the discourses within which we operate". Additionally, Csikszentmihalyi [16] mentions that creativity in teaching takes place when a teacher combines existing knowledge in some novel or unique way or introduces new processes to cultivate cognition to get useful results. In brief, creative teaching is when teachers can empower their students to know how to learn, and how to learn independently [64] (p. 9). A creative act only makes sense in relation to a particular situation. This context-based creativity is certainly in conjunction with Kumaravadivelu's [37], [39], first parameter of PMP, the particularity. Put differently, creativity is a unique ability of teachers to take ownership of their own practice by ensuring the transformed knowledge and skills are relevant to students' needs and meaningful for their future life.

\subsubsection{Features of TC}

In addition, Richards and Cotterall [53] underpin that creative teachers in language teaching are characterized by at least four features. First, the teacher is not committed to a single approach or method. Second, the teacher is confident and willing to make his or her own decisions about how to change classes. Third, the teacher adjusts and modifies her teaching during lessons. Fourth, the teacher customizes his or her teaching (p. 99-107). Richards [52] underlies that being creative means being reflective, that is willing to review their own practice, expand their knowledge and find new ideas to be practiced in their classrooms (p. 30). This means that teachers do not simply present lessons from the book, but they look for original ways of creating motivating lessons that make students engaged to learn. Kumaravadivelu [40] (p. 4) views creativity as central to successful teaching and learning, not an "optional" component in language teaching, something "tacked onto" our lessons just to make them more interesting. According to Pennycook [50], creative language use and creative language teaching are often a matter of refashioning, re-contextualizing, and building upon the words and ideas of others. In the same vein, Maley and Bolitho [45] (p. 434) asserts that 'we should judge creativity in the classroom by what the teacher makes possible for the student to do, not just by what the teacher does.' Conclusively, creative teaching especially in language teaching, therefore, is seen and supposed to involve teachers in making learning more interesting and effective and using imaginative approaches in the classroom [12]. The TC spotted in this research is a sort of teachers' initiatives to improve the ways they approach their teaching to make it more interesting for students to follow so the classroom learning become more engaging. Creativity here is perceived as an enabling and empowering act for students' learning.

\subsection{Preview of Recent studies on RP and TC}

There has been an extensive body of theoretical work about creativity but relatively little in terms of research especially in the area of ELT [1], [49]. Too, lots of literature on RP on 
education in general but minimum with data-led or research-based descriptions [70] especially on how it is actually realized in the field. In Indonesian context, these two have not been extensively researched especially on how RP and creativity are exercised in the classroom. Very few research on the issues has been carried out [2], [44], [18], [68] in the context of the current study. One study, taking Cyprus as a context, on the impact of guided reflective practice on the teaching of English as a foreign language in higher education suggests "an increased self-awareness and awareness of practice, an ability to critically reflect on context without being judgmental of others, and a willingness to reframe practice" [13] (p. 189). This indicates that RP has potential for professional teaching development. In terms of TC, another study, taking Kuwait as a context, shows that creativity plays an important role in "enabling the meeting of learners' needs and employing English in the learners' interests, as well as encouraging peer-interaction". The study also indicates that creativity is a "skill which can be learned' and involves 'teaching beyond curriculum" [1] (p. 244). These facts suggest that the current study on RP and TC within the frame of PMP in Indonesian context is worth exploring as it can potentially fill the gap in the paucity of the empirical studies in this research context.

\subsection{Research Design}

The qualitative research design used in this research is phenomenology. Phenomenology was founded on the basis that "what needed to be examined was the way people lived in the world' [57] (p. 213). Phenomenology is a research approach that attempts to uncover what several participants who experience a phenomenon have in common [15], and that seeks not only to uncover what individuals experience but also how they experience the phenomenon [57] (p. 215). Hence, phenomenology can be understood as the direct investigation and description of phenomena as consciously experienced by people living those experiences. The data were collected from individuals (ELT practitioners) who have experienced the phenomena through observation and interview of small samples of participants in terms of their ELT classroom practices. This research intends to identify what they plan, what they do, how they customize their lesson, how they adjust their lesson plans, how they solve problems, and how they approach their teaching or so-called 'lived experiences as described by the experiencers' [26] (p. 178) via the lenses of their RP and TC set within the paradigm of postmethod pedagogy. The common phenomena of interest in this research are RP and TC as perceived and practiced by Indonesian ELT practitioners. The findings are then presented in a composite description and a plausible interpretation. Hence, this phenomenological research is set in a descriptive-interpretive mode. Again, the purpose of this research is to describe the extent to which the phenomena (RP and TC) are perceived, practiced and experienced by Indonesian ELT practitioners in their teaching practices as a way to understand the degree PMP has been put into practice as implied in the threefold research questions mentioned in the abstract of this paper

\subsubsection{Context and participants}

The context of this study was the teaching perspectives and practices of ELT practitioners teaching at senior secondary schools and tertiary levels at the regency of Banyumas, central java, Indonesia. The participants of the research were ELT teachers who have been teaching English for at least five years at secondary schools and universities. All the participants were private permanent academic staff or civil servants and have handled a variety of classes with different levels of proficiency (Year 10 to Year 12 for schools teachers and Semester 1 to Semester 10 for university teachers). Both voluntary system and purposive sampling were 
used in selecting the samples. Their participation was fully voluntary only based on their own willingness to participate and they had the full right to withdraw from the research at any time they consider appropriate to do so. As the name suggests, the purposive sample in this research has been chosen for a specific purpose [10]. The criteria set for the sample were that the samples were the ELT practitioners who have been teaching at least for 5 years and teaching at either universities or secondary high schools.

\subsubsection{Data Collection}

The data used and analysed in in this paper were collected in three data collection techniques: observation, interview and documents.

\subsubsection{Observation}

An observation is a way for a researcher to document everyday practices of participants and to better understand their experiences [57]. Since this is a classroom observation, I served as an unobtrusive observer who aimed at documenting, describing complex classroom actions and interactions [46], or a complete observer [10] who only observed and was detached from the group, or a passive observer [61] or passive participant [57], as I did not interact with the participants I was observing to avoid potentially biasing the observation and just observed teaching learning activities without engaging in them directly [41]. In the research I observed 8 ELT practitioners, teaching twice in the same classes with different topics.

\subsubsection{Interview}

An interview is a conversation between two individuals in which the interviewer asks questions and the interviewee responds [57]. In this research I used a semi-structured interview, where the questions were predetermined but the order were modified based the perception of what seemed most appropriate [54]. In it, I also included additional questions in response to participants' comments and reactions.

In this interview, I explored their perspectives on the ideas of RP as well as TC. Although I prepared a list of questions, the interviewees were set free to express their ideas related to the given topic [5]. This was aimed at capturing descriptive data about the interviewees' ideas, attitudes and perceptions about (directly or indirectly related to) RP and TC in their respective classroom teaching. Sometimes, some additional points were also questioned and answered based on what I thought was important and necessary. Practically, I did post-classroom observation interviews twice with all 8 participants. However, only two interviewees were considered in this paper.

\subsubsection{Documents}

To complement the data collected through observation and interview, I added documents study. Savin-Baden and Major [57] define documents as any written, printed, visual or electronic matter that provides information or evidence or that serves as an official record. For this research, the documents to be investigated and studied comprise of 1) teacher's textbooks, manuals, teaching journal; 2) students' records, work, test results, daily and weekly performance appraisal, 3) school and university curriculum, syllabuses, students' register.

\subsubsection{Data analysis and interpretation}

In analysing the observation and interview data, I just employed content analysis (CA) in order to get a compact data set so that I was able to generate codes, categories and themes and an overarching theme. 


\section{Content analysis}

In general, the CA I conducted was based on the processes and procedures proposed by Elo and Kyngas [19] shown in Table 1 below.

Table 1. Processes of data analysis in content analysis

\begin{tabular}{ll}
\hline Analysis phases & \multicolumn{1}{c}{ Descriptions } \\
\hline Preparation & $\begin{array}{l}\text { Being immersed in the data and obtaining the sense of whole, selecting the } \\
\text { unit of analysis, deciding on the analysis of manifest content or latent } \\
\text { content. }\end{array}$ \\
Organizing & $\begin{array}{l}\text { Open coding and creating categories, grouping codes under higher order } \\
\text { headings, formulating a general description of the research topic through } \\
\text { generating categories and subcategories as abstracting. } \\
\text { Reporting the analysing process and the results through models, conceptual } \\
\text { systems, conceptual map or categories, and a story line. }\end{array}$ \\
\hline
\end{tabular}

Since the defining feature of CA is the process of data summarizing and reporting, this CA focused on summarizing and reporting the contents and messages of the data [10]. CA also known for its strict and systematic set of procedures for the rigorous analysis, examination and verification of the contents of written data [48], [23], it should result in replicability and transferability of the inferences from texts (data) to the contexts of their use [33], implying that texts cannot be detached from its contexts. Hence, the qualitative meanings of my data should be described and contextualized [60]. I did this through assigning successive parts of the material to the codes, categories and themes, which contained all those aspects of RP. The main goal in this CA has been to seek to arrive at an understanding of a particular phenomenon from the perspective of those (ELT practitioners) experiencing it [69].

\subsection{Findings and discussions}

The findings and discussions are based on the results of CA of observation and interview plus documents on the aspects of both RP and TC, as shown in Table 2 below.

Table 2. Results of CA

\begin{tabular}{|c|c|c|c|c|c|}
\hline Overarch & \multicolumn{5}{|c|}{ Localized PMP in contextualized RP and TC } \\
\hline Themes & \multicolumn{3}{|c|}{$\begin{array}{c}\text { Improving teaching through RP (thinking, evaluating and } \\
\text { changing) }\end{array}$} & \multicolumn{2}{|c|}{$\begin{array}{l}\text { Empowering teaching } \\
\text { through TC (exploring, } \\
\text { identifying and } \\
\text { experimenting) }\end{array}$} \\
\hline Categories & $\begin{array}{l}\text { Reflection-in- } \\
\text { action }\end{array}$ & $\begin{array}{l}\text { Reflection-on- } \\
\text { action }\end{array}$ & $\begin{array}{l}\text { Reflection-for- } \\
\text { action }\end{array}$ & $\begin{array}{l}\text { Exploring } \\
\text { teaching } \\
\text { materials }\end{array}$ & $\begin{array}{l}\text { Identifying } \\
\text { teaching } \\
\text { strategies }\end{array}$ \\
\hline Codes & $\begin{array}{l}\text { Adjusting } \\
\text { change in } \\
\text { teaching } \\
\text { process }\end{array}$ & $\begin{array}{l}\text { Evaluating for } \\
\text { learning } \\
\text { improvement }\end{array}$ & $\begin{array}{l}\text { Evaluating and } \\
\text { planning teaching } \\
\text { practice }\end{array}$ & $\begin{array}{l}\text { Stimulating } \\
\text { learning }\end{array}$ & $\begin{array}{l}\text { Activating } \\
\text { learning }\end{array}$ \\
\hline $\begin{array}{l}\text { Units of } \\
\text { analysis }\end{array}$ & $\begin{array}{l}\text { Changing } \\
\text { topic of } \\
\text { discussion }\end{array}$ & $\begin{array}{l}\text { Increasing } \\
\text { students' } \\
\text { motivation }\end{array}$ & $\begin{array}{l}\text { MGMP } \\
\text { (Community of } \\
\text { practice) }\end{array}$ & $\begin{array}{l}\text { Using } \\
\text { authentic } \\
\text { materials } \\
\text { Using songs }\end{array}$ & $\begin{array}{l}\text { Using games } \\
\text { Picture } \\
\text { drawing }\end{array}$ \\
\hline
\end{tabular}


The findings and discussions are based three explorative questions posed earlier that are arranged in a sequential order: RP and TC. RP is the first to address in this paper. As learnt that reflective evaluation is an indispensable aspect of language teaching, without which teachers just practice their routine and habit. Teaching itself is a reflective activity as it is hard to imagine a teacher who does not think when designing, planning and acting his teaching. Evaluation is usually conducted through self-reflection. This implies a reflective teaching whereby teachers engage in a successive series of reflection and modification. That is, reflective teachers reflect on their own teaching practice (i.e., self-observation) and then modify their practice (i.e., self-evaluation) to make sure the outcome will be satisfactory [55]. How reflective Indonesian ELT practitioners will suggest the answers to the following explorative research questions.

\subsubsection{In what ways are Indonesian ELT practitioners reflective in their teaching practice?}

The answers for this query will be clustered into three categories: reflection-in-action, reflection-on-action and reflection-for-action.

\subsubsection{Reflection-in-action}

Reflection is an ongoing process which requires practitioners to engage in a continuous cycle of observation-of-the-self and evaluation-of-the-self, whose aim is to help practitioners understand their own actions as well as the reactions they stimulate in their interlocutors [6], [67]. Reflection-in-action as one kind of RP suggests a direct evaluation on how teaching flows in the process of teaching. This reflection-in-action was marked by the process of changing topic of discussion.

a) What was the lesson?

The course that I observed was Intermediate Integrated Course Practicum. This practicum is a supplementary subject aimed to support the main subject, the Intermediate Integrated Course. This practicum course comprises of the teaching learning materials that can help students to increase their ability to use the four language skills in expressing things in a descriptive and argumentative way. According to the description of its general competence, this course is aimed at enabling students to communicate in an intermediate level by using the four language skills properly. The topic of the lesson was on Family Matters and the sub topics were Grammar on making comparison and Questions with look like, be like, and like, Vocabulary on family relationship, Reading on family stories, Listening on TV Shows and Personalities, Speaking on describing a person, describing personalities and family relationship, and Writing on My family.

b) What was planned?

In the lesson plan, the activities planned to be executed were not specified in detail. They were written in brief which only covered such activities as discussion, role play, practices in listening, reading, and writing which were referred to as integrated activities. What was planned for a class discussion was that students were requested to bring text or learning materials on family matters, which the students had forgotten to prepare and bring to the class. One of the students said that the teacher had not asked to prepare or bring an article or text, but only to discuss about family matters. Another student even thought that the topic was still on sports. This situation is visualized in Excerpt 1 containing a dialogue between participant eight (P8) and his students in the opening part of his teaching.

Excerpt 1:

P8: This morning.. You're going...we're going to talk about family.. you are going to 


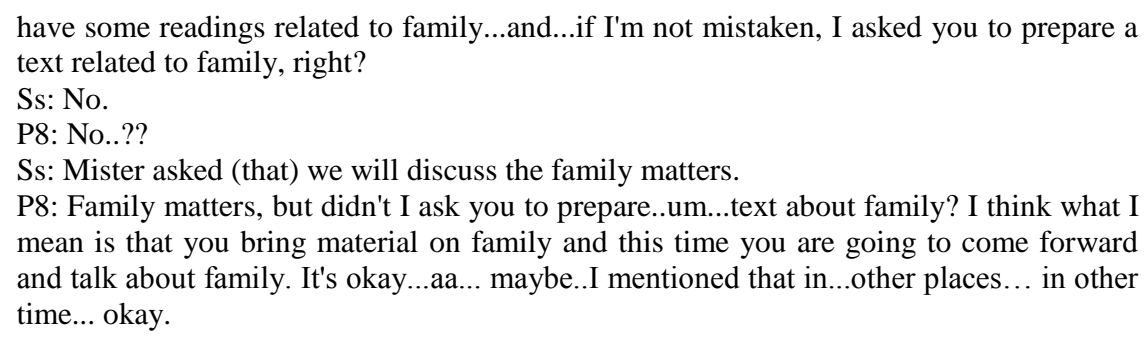

Observation with P8: C1C1U1

Excerpt 1 indicates that P8 actually have planned to talk about family matters and therefore in the previous meeting he asked his students to prepare a text or an article about family. Hence, he checked his students' readiness about the text. Yet, his students' response was the opposite of his hope, informing that their teacher had not requested it. Even one of his students claimed that the topic is still on sports. P8 was trying not to show directly his disappointment. Yet, P8 tried to reassure that he earnestly has asked his students to bring the material. Probably, P8 was trying to indicate his soft disappointment by saying "It's okay...aa... maybe..I mentioned that in...other places... in other time”. Instead of exploring the reasons why his students did not prepare the text from home, he tried to think and finally found an alternative activity very spontaneously, as spelled out in the next part.

c) What was done?

Since the students did not bring any material related to family, P8 smilingly asked his students to see the textbook, indicating the output of his spontaneous reflectioninaction, as seen in Excerpt 2. P8 realized what was practical to be done in that situation. So, this reflection-in-action output is the actualization of pedagogy of practicality featuring the PMP.

Excerpt 2:

P8: It's okay. aa.. so you need.. You need to open your material, your book. Uumm..the first person that you know in this world are your parents, right? Your mother and your father? And they are part of your family. And..talking about family..um...

Now, let's read this the text related to family that is provided in the material, in your book. The first is.. um...text which is related to...parents-children relationship..on the...the first page of your book.

Observation with P8: C1C1U2

Excerpt 2 indicates that there is an abrupt and spontaneous decision and action to switch to another activity, from reading and discussion texts of family supposedly prepared by students (as planned though not detailed in the lesson plan) towards reading and discussing a text from the students' textbook. P8's idea was to ensure that learning should carry on and become effective. This instant switch of activity is a part of reflective thinking and reflectionin-action, further confirmed in the interview result as shown in the next section.

d) Why is the difference a reflection-in-action?

The difference in what was planned and what was done in P8's teaching activity is certainly a representation of reflection-in-action, the thinking in the action, creating another action, performed instantly. This new action, on-the-spot experimentation [58], [20], asking students to read and discuss a similar topic in their textbook, is verified through the following excerpt.

Excerpt 3:

R: Hmm. I realized from your interaction that actually you have asked them to prepare their article from home?

P8: Yea. To read and to prepare the text and to present it in the class. I asked them to learn the 
texts together first before coming to the class. But, seemingly they misunderstood the instruction. R: Seemingly so. Or maybe they just pretended.

P8: I didn't know exactly. But what I knew was that they looked not well-prepared. Eventually, I directly changed the design of learning.

R: Hmm.

P8: Since that has happened as such, we had to do something in order to keep the learning. Interview with P8: C1C1U3

Excerpt 3 justifies the conclusion that P8 did a reflection-in-action when he said," I directly changed the design of learning" and "we had to do something in order to keep the learning." In that situation, P8 was probably thinking that his students misunderstood his command due to the command itself was not clearly expressed. But, in that particular moment such assumption was not that important. What was pivotal for him as a teacher was to figure out a way forward for the teaching learning process. In short, with its complexities, there is always a unique experience taking place in every teacher's classroom. In such state, there exists thought in action and action in thought called reflection-in-action, an action for improvisation of teaching and learning.

\subsubsection{Reflection-on-action}

Reflection-on-action is the second type of reflection in RP. Slightly different from the stance of reflection-in-action, this reflection-on-action means looking back, in this regard, looking back at the teaching learning process to identify aspects of teaching and learning that can be improved in the next teaching or action. This, in Ghaye's view [25], signifies that the action is a kind of 'a deliberate, conscious and public activity principally designed to improve future action' (p. 25). So, the basic tenet of this reflection is similar to the previous reflection, which is to improve students' learning process. This reflection-on-action tends to be specifically undertaken after the event, problem or situation that initiated the process [63]. One form of reflection-on-action identified in this study is increasing students' motivation.

As widely conceived that motivation has an important role in language learning. The students who have high level of motivation will learn faster and more productively than those who have low level of motivation. Research shown that the students who had positive motivation and attitudes toward language study tended to do well in their learning, or motivated students studied regularly and productively in order to take every opportunity to perfect their language skills [66]. Lacking motivation to learn also became one of the problems faced by P1's students, as shown in Excerpt 4 below.

Excerpt 4:

R: So, in your evaluation do you often get a better solution for teaching?

P1: Yea, looking for methods like this way: if a method is undoable it has to be changed again like this, and the next day to be changed like that. I mean we have to look for a way out frequently.

$\mathrm{R}$ : Based on your teaching evaluation, what do you think you need to do to improve English teaching and learning?

P1: I think the first thing to do here related to English is to give motivation. Yeah..to raise spirit, to live up their motivation, and I think one of the ways is to invite a native speaker once in a semester and this can boost their enthusiasm. The point is how to make my students more enthusiastic, more motivated to learn English.

Interview with P1: C2C2U1

In this excerpt, $\mathrm{P} 4$ pointed out utterly that he often does self-evaluation on the conduct of his own teaching. He seemed to count on the idea that a teacher who often does self-evaluation will be more capable of enhancing his or her own teaching performance which can improve his or her students' learning. P1 also contends that as an ELT practitioner she needs to reflect 
on her own teaching to see what fits well and what does not. If, according to her, one teaching method does not work well then it has to be evaluated and changed. She seemed to give a message that ELT teachers need to do RP in their practice. Teachers should consider seriously the efficacy of their teaching approach, appropriateness of teaching materials, and the like. P1 also mentioned that her students' motivation in learning English was not that high. Therefore, P4 proposed one solution to inject and boost the students' motivation the school. In her mind, the school needed to invite native speakers of English to come to his school. According to P1, the presence of native speakers in his school can uplift students' enthusiasm to learn English since P1 had proved this approach beforehand. The main point indicated by P4's reflective teaching is that her teaching has to make his students more enthusiastic, more motivated and more able to understand the lesson. Ensuring that inviting native speakers can improve students' motivation to learn English reflects the realization of pedagogy of particularity as this particular solution just seems to fit such particular students' needs in that particular school. Since P1 is the teacher who has been teaching in the school for years, he knows quite well what his students need in order to upgrade their motivation. This decision or intention was based on his previous experience.

\subsubsection{Reflection-for-action}

Reflection-for-action is the manifestation of both reflection-in-action and reflection-onaction. It is, according to Farrell [20] 'the desired outcome of both reflection-in-action and reflection-on-action, which enables teachers to prepare for the future by using knowledge from what happened during class and what they reflected on after class' (p. 6). How the Indonesian ELT practitioners have practiced reflection-for-action so that they become better informed on their practice through which they can have a better plan for a better action in the future. In this research, one type of reflection-for-action identified is MGMP (Teachers's Forum for Related Courses) or better known as Community of practice.

There is no doubt that sharing information, knowledge and experience and working together among teachers to solve their teaching learning problems is more effective than doing it individually. The idea of working together within the school teachers has been facilitated through so-called community of practice (CoP), a group of people who share a craft or a profession [42], better known among Indonesian school teachers as MGMP (Subject Matter Teachers' Forum). This MGMP (CoP) serves as an effective forum for sharing and discussing teachers' teaching problems, problem-solving activities, workshop on teaching, teaching planning, teaching material design agenda, etc. Due to nature of MGMP which is a forum to share, discuss and plan for future action in their respective schools, it is much nearer to the area of reflection-for-action. In MGMP, rather than an individual reflection and action, it is more in the approach of collective thinking and action. The advantages of this MGMP are highlighted Excerpt 5 below.

Excerpt 5:

R: In your opinion, what are the barriers that make most teachers unable to share ideas at schools with their colleagues regarding their teaching?

P3: So far maybe because every teacher is busy with his or her own business. However, ideasharing can only be done effectively in teachers' forum, MGMP, a forum for sharing ideas among teachers of the same domain.

R: MGMP? Tell me more about it please.

P3: In this forum, there will be so many English teachers from different schools who come to share their ideas, knowledge, information, and experiences. Many new things will come up that we can apply in our respective schools.

R: Do you feel free to talk about anything regarding teaching and learning in MGMP? 
P3: Free. We don't feel uneasy or hard feeling and so on. All teaching learning problems will come up in the meeting. What we talk about in MGMP is not only about teaching techniques, but also about any latest issues or educational policies. In the lasts meeting, we talked about test construction.

Interview with P3: C3C3U1

Excerpt 5 denotes that MGMP as a community of practice plays a pivotal role as a medium for knowledge-sharing, information dissemination, program evaluation, teaching planning, training for teaching, material design and other teaching learning-related matters. All members have shared- freedom to raise any teaching issues occurring in their respective schools and each is called to actively give their ideas for the common sake. In this forum, ELT practitioners have so called "Esprit de corps" a shared morale of the group of ELT professionals. In that forum, they even discuss issues regarding local or national educational policies and local and national exam materials. All these are discussed relaxingly and freely where all ideas are welcome. Any solution for any school-related problem is formulated together to be brought back to their school. From this picture, it can be said that the forum is opaquely aimed for professional teacher development individually and collectively. Other valuable benefits are also shared by $\mathrm{P} 2$ as shown in Excerpt 6 below.

Excerpt 6:

P2: Okay, actually MGMP has many advantages. At school level, it is related to the aspects of syllabus design, either adapted or adopted one. Usually, in the school level, it's all about the divide of teaching hours and learning assessment.

A: What about at the regency level?

P2: For the regency level, there are many things to do. We also share our research report there. We also have such programs as UKG (teachers' competency test), PKG (teachers' competency assessment). In this MGMP, we also share our teaching problems, teaching techniques, how to do a cloze procedure, and so on. We then try to solve the problems together. We also discuss about ceremonial programs like English contests at regency level because similar programs will be held in province level.

Interview with P2: C3C3U2

Excerpt 6 suggests that MGMP also prevails within school level whose main programs are linked to syllabus design either adapted or adopted one, teaching time allotment, and learning assessment. As mentioned by P2, MGMP also operates within regency level of which they can share their research report, programs of UKG (teachers' competency test) and PKG (teachers' competency assessment), teaching problems as well as teaching techniques, and technical aspects of a cloze procedure (a reading comprehension activity in which words are omitted from a passage and students are required to fill in the blanks). In addition, teachers in MGMP discuss and prepare about regular and ceremonial programs like English contests at regency level because similar programs will be held in province level. It can be inferred that MGMP having a variety of meaningful programs can serve as a practical medium for all ELT teachers to exercise their reflection-for-action since within the programs teachers collectively set an action plan for ELT improvement in their own schools collectively and professional development individually.

The MGMP's programs that are aimed to mediate teachers' professional development and to improve teachers' teaching competence strongly indicate an element of pedagogy of empowerment. In the MGMP teachers have freedom to express and share their ideas on how to improve their pedagogical practice in their schools. In it, they learn together and develop together. This facilitates the possibility of power for teachers to do something related and relevant with their job as a teacher. This also makes teachers more confident in the acts of teaching. This MGMP characterizes the pedagogy of possibility as it is designed to empower 
teachers to develop theories, knowledge and practices that work with their own pedagogical setting.

\subsubsection{In what ways are Indonesian ELT practitioners creative in their teaching practice?}

The results of the data analysis suggest that Indonesian ELT practitioners are creative at least in two main modes of practice, exploring teaching materials and identifying teaching strategies, as presented successively below.

\subsubsection{Exploring teaching materials}

Teaching and learning are two essential entities in language pedagogy. In many ways, they are unseparated and interrelated. According to Brown [7], teaching cannot be defined apart from learning. That is, teaching is guiding and facilitating learning, enabling the learner to learn, setting the conditions for learning. To be a good learning guide, teachers need not only to be reflective but also creative in their teaching practice. Creative teaching [64] (p. 3) is about how teachers present themselves as someone who cares and enjoys teaching their subject, how they motivate their pupils to participate and understand, how they go about making learning more fun or engaging, how they spot opportunities to liven things up and how they encourage pupils to take responsibility for their work in a way that does not feel like a burden to the students and the teachers. All these explorative teaching activities are aimed to stimulate students' active, interactive and engaging learning. Realizing the values of these stimulating learning activities for their students, the Indonesian ELT practitioners explored such high impact possibilities through the exploration and creation of appealing authentic materials and customization of English songs.

a) Using authentic materials

Using authentic materials can be more imaginative and motivating for students compared to using the published textbooks. Authentic materials not only refer to newspaper and magazine articles, but also encompass such things as songs, web pages, radio and TV broadcasts, films, leaflets, flyers, posters, and anything written in the target language and used unedited in the classroom [62]. The creative use of the authentic materials was also performed by $\mathrm{P} 2$ as hinted in Excerpt 7 below.

Excerpt 7:

$\mathrm{R}$ : All right. If it is in percentage, how often do you use authentic materials for your teaching?

P2: Well, I myself use $60 \%$ from me, myself, and the rest is from authentic materials. I look for the materials, I like to use authentic ones. For example, for news item I usually go to the library to seek the authentic material, adapt it accordingly.

R: I see.

P2: I just focus on the vocabularies often used in the texts but for further teaching materials I prefer to use authentic materials such as the recipes found in the newspaper, magazines, and so on. Usually I ask students to find a recipe and to demonstrate it in group. So, the percentage of using the authentic materials is around $60 \%$, and $40 \%$ from the books.

Interview with $\mathrm{P} 2$ : C4C4U1

Excerpt 7 shows P2's favour and high frequency of using the authentic materials where P2 used around $60 \%$. She realized that the authentic materials were not teaching materials per se. However, she used her creativity to adopt and adapt some aspects of the materials and designed them to be captivating teaching materials. She had the same reason for using the authentic materials as P1 had, namely the contents of the given textbooks lacked of interest for 
the students. P2 reasoned that the use of the authentic materials was aimed to prepare her students to be ready with any possibility in the examination be it the local or the national one. Thus, the blending of both syllabus-based textbooks and the authentic materials is a manifestation of P2's creativity in her language teaching. This seems to belong to the pedagogy of both particularity and practicality since using authentic materials are bound to the context specific of P2's circumstances. Besides, the use of $60 \%$ material-authentic indicates that $\mathrm{P} 2$ has come to a phase of practicing her theory and theorizing her practice due to the fact that she has been rich in teaching experience.

As mentioned earlier, the second mode of creative practice of Indonesian ELT practitioners were manifested through the use of English songs as teaching-learning materials.

b) Using songs

Using authentic materials can be more imaginative and motivating for students compared to using the published textbooks. In other words, authentic materials include print, video, and audio materials students encounter in their daily lives [62]. Song is a part of an audio and video. P1 pointed out that using a song in classroom learning is more stimulating for students to learn, as indicated in Excerpt 8 below.

Excerpt 8:

P1: The good teaching material for me is when it can console my students in learning.

This happened when I taught English using songs.

R: English songs?

P1: Yes. English songs. In the $13^{\text {th }}$ curriculum, there is a teaching material using songs. But based on teachers' forum agreement that will be given in semester 2 (year 12). So, for this semester it has not been given yet, but last year I tried to teach using songs and students' enthusiasm was actually higher than when they were taught using reading texts. Interview with P1: C4C4U2

According to P1, based on Excerpt 8, using songs by singing together the students felt excited even they did not know the meaning of all the lyrics. This fun learning, in P1's idea, helps students some vocabularies, pronunciation, and understanding about the message of the song. So, P1 adds that the students' vocabularies get increased which can be used indirectly in other materials like in reading texts. Using songs as teaching materials also need creativity as songs are actually not designed as teaching materials. The idea of using songs as teaching materials for P1 was to arouse his students' enthusiasm to learn. In P1's view, songs can help students to learn how to pronounce English words correctly and improve their vocabulary. The important thing, according to P1, is that students become eager to learn. Again, the use of songs as teaching materials are motivated by the elements of practicality in P1's context and that of particularity which is adjusted to the actual needs of P1's students. It is very contextualized and proportional.

In addition to exploring authentic materials and English songs to stimulate their studnets ${ }^{6}$ learning, Indonesian ELT practitioners likewise identified teaching strategies to activate their learning, to make them interact in a fun and engaging way.

\subsubsection{Identifying teaching strategies}

Teaching strategy is a kind of methods used to help students learn the desired course contents and be able to develop achievable goals in the future. Two samples taken from the results of CA are picture drawing strategy and using guessing games.

a) Picture drawing strategy

In delivering their subjects, Indonesian ELT practitioners have demonstrated varied teaching strategies or techniques by which their students can learn their lesson effectively. Of course, different teachers have different teaching strategies, usually based on their experience, 
knowledge, skills and teaching contexts. Within the context of Indonesia, ELT practitioners have shown their unique and meaningful strategies, as denoted in Excerpt 9.

Excerpt 9:

P5: So, students can ease their memorization of the main idea of a text by drawing a picture representing the content of the text. So, from the first paragraph up to the last paragraph, the students will draw pictures to help them remember the order of the story within the text.

$\mathrm{R}$ : If there are five paragraphs there will be five pictures. Is it?

P5: Five pictures, but if they want to make more than five pictures, that is fine. So it is like story telling picture.

R: Without a text at all?

P5: Without a text, but picture only. After the students make a complete series of pictures, they emm what is it? They memorize the content of the story. Later they will stand in front of the class without bringing the texts they will retell the story while bringing the pictures they have drawn.

Interview with P4: C5C5U1

Excerpt 9 tells how P5 set out her teaching strategy creatively. P4 called it "Picture Drawing" strategy. This strategy was asking students to work in a group in which they have to draw pictures based on the content of paragraphs in a reading text. Here, students share their task evenly. One student is responsible for reading and understanding the text, another one for drawing a picture, and another one for retelling the content of the text represented by the pictures in front of the class. The number of pictures relies on the number of paragraphs. These pictures serve as a tool to help students (presenters) to memorize the contents of the text since the students are not allowed to bring the text with them when retelling the "story" of the text. The most "challenging" task is certainly on the drawing of the picture as it needs an imaginative ability to be able to represent the idea of a text into pictures. Yet, that is where the value of this strategy lies.

As understood that a strategy as a way of achieving something. So this teaching strategy is the way P5 took to make her teaching understandable so her students can learn meaningfully as this can help students learn and understand the contents of the reading texts. Thus, it is clear that P5 empowered her students to work together, to think together and to draw fitting pictures together. Besides, this strategy is very practicality-oriented. P5's own theory of teaching practice has taken shape where understanding text can be done in many unique and interesting ways. This strategy clearly involves students' imagination, understanding and skills that solidify students' text comprehension. This truly represents the pedagogy of possibility and practicality.

b) Using guessing games

Classroom environment is crucial to the fostering of creative abilities. According to Joubert [29], creativity can be stimulated by an environment full of ideas, experiences, interesting materials and resources, and in a relaxing atmosphere where unique ideas are encouraged. A game can stimulate this sort of environment. It is an activity usually involving skill, knowledge, or chance, following fixed rules and trying to win against an opponent or solving a puzzle. P5 used a guessing game, where a student is pantomiming an imagined activity, as contained in Excerpt 10.

Excerpt 10:

P7: eee... The game that I used to teach Grammar was a guessing game. For example, to teach Continuous Tense I used the guessing game of "What am I doing?" So, the student made an action to be guessed by every group members except by his or her own group. R: Every group, Okay.

P7: They plan the action and present it in from of the class. So I made some groups and 
each group member had to make one sentence with its action. That sentence is what members of the other groups have to guess. All the sentences have to use continuous forms. If the sentence they made was "I am taking a bath" they have to demonstrate as if they were taking a bath. Those who can guess correctly will get 3 points. I collected and recorded the points in the student register which I use as additional basis for the final score.

Interview with P7: C5C5U2

The guessing game above is considered a creative mode of teaching as it involves particular skill and creative thinking not purely based on luck. This game encourages students' creative thinking, thinking of a new sentence, a new demonstration and new guessing. This creative game seems to foster students' creativity as well as it is developed through mental play or thoughtful playfulness, involving conjuring up, exploring and developing ideas or possibilities [28]. Another similar type of game but distinct in the way how it is performed was also used by P3 in her teaching. It is still a guessing game but without any demonstration. Instead, it needs more clues, more explanations, and more samples in order to be correctly guessed. This is called " 21 questions game", asking students to guess what an alphabetical letter means or stands for. P2 gave an example: "What is A? " and giving some clues like "I like A. It is a kind of fruit". Then, the students have to guess it. If the clues were insufficient, she added the clues such as "The colour is usually green" emm "The town where it is famous Malang (name of a town in East Java)".

This game requires a teacher or a student to be able to provide as many description or explanation or examples as possible related to the thing being questioned and guessed. It also needs an imaginative thinking and general knowledge to identify the object precisely. Craft [11] suggested that a play or game is considered a creativity when it is 'epistemic play' (p. 154) (where students exploring the properties of materials and developing knowledge and skills which underpin later learning). According to P3, this game was used to consolidating her students' understanding on the teaching materials. This game is considered a creative way of teaching as it may foster students' creativity, in helping the students to explore possibilities and deepen their knowledge of materials given by their teacher.

Like picture-drawing strategy, using songs strategy has the element of empowerment and motivational development instilled in the students' learning cognition and attitude towards English as a foreign language. It gives a message that it is a field that is pleasant and easy to learn. Eventually, the teaching creativity as indicated by the Indonesian ELT practitioners in the foregoing discussions is a kind of thought in act by which they can spotlight the genesis of a living class, an engaging class, an interactive class, and an effective class. It is an individual act which is particular, practical and possible in the milieu of liberating pedagogy, PMP.

\section{Conclusion}

The conclusion of this paper is set out as the answer for the last query: To what extent are Indonesian ELT practitioners post-method-oriented in their teaching practice? Based on the results of the findings and discussions, it can be summed up that, within the context of research, Indonesian ELT practitioners are reflective practitioners as they do reflection-inaction, reflection-on-action and reflection-for-action in their teaching practices. They are thinking about their practice, they are evaluating their teaching performance, they are making adjustment in their lessons, and they are making a change where necessary based on what is 
particular and practical in their teaching contexts. They are also considered about their professional development by actively involving in their MGMP (CoP) programs.

In addition, Indonesian ELT practitioners are also identified to be creative in handling their teaching activities. They are creative in using teaching materials, in designing teaching strategies, and implementing as well as in evaluating what seems to work well and what needs to be improved. It was also found that Indonesian ELT practitioners do not adhere to any teaching method but mostly develop and use their own teaching approaches that are based on their knowledge, understanding and experiences that they have built up during their teaching practices. These self-initiated creative modes of teaching that are based on continuous selfobservation, evaluation and reflection are considered to be unique, specific and contextualized. Arguably, the Indonesian ELT practitioners are, to a large degree, reflective, creative and postmethod oriented.

\section{Acknowledgments}

My first and foremost thanks go to LPDP (Indonesia Endowment Fund for Education) for financing this research. My high appreciation to all school principals, Deans, respondents and participants of the institutions in Purwokerto within which this study was carried out. My special thanks are extended to Dr. Richard Kiely for his constructive feedback on the writingup of this article.

\section{References}

[1] Al Khars, D. A. M. A.: Creativity in English language teaching in Kuwait: A TESOL study. An unpublished thesis. University of Exeter (2013) Available online at: https://core.ac.uk/download/pdf/18460321.pdf

[2] Azizah, U. A., Nurkamto, J., \& Drajati, N. A.: Reflective practice: The experiences of preservice EFL teachers in teaching English. Journal of Language and Linguistic Studies, Vol. 14, pp. 133-144 (2018) Available online at www.jlls.org

[3] Baldez, P. N., Navera, J. A., and Esteron, J. J.: What is Reflective Teaching? Lessons Learned from ELT Teachers from the Philippines. The Asia-Pacific Education Researcher, Vol. 27, pp. 91-98 (2018) Available at: https://link.springer.com/article/10.1007/s40299-018-0368-3

[4] Boden, M. A.: The creative mind myths and mechanism. ( $2^{\text {nd }}$ Ed.). London: Routledge (2004)

[5] Boyce, C. and Neale, P.: Interviews: A guide for designing and conducting in-depth interview for Evaluation input (2006) Available at: http://www2.pathfinder.org/site/DocServer/m_e_tool_series_indepth_interviews.pdf

[6] Brookfield, S. D.: Becoming a critically reflective teacher. San Francisco, CA: Jossey-Bass (1995)

[7] Brown, H. D.: Principles of Language Learning and Teaching: A course in second language acquisition (6 $6^{\text {th }}$ Ed.). Upper Saddle River: Pearson Education (2014)

[8] Canagarajah, A. S. (Ed.): Reclaiming the Local in Language Policy and Practice. Mahwah, New Jersey: Lawrence Erlbaum (2005)

[9] Carter, R.: Language and creativity: The art of common talk. London: Routledge (2004)

[10] Cohen, L., Manion, L., and Morrison, K.: Research methods in education. ( $7^{\text {th }}$ Ed.). London: Routledge (2011)

[11] Craft, A.: Creativity and early years education: A lifewide foundation. London: Continuum (2002)

[12] Cremin, T.: Creative teachers and creative teaching. In Wilson, A. (ed.) (2 ${ }^{\text {nd }}$ ed.) Creativity in primary education: Exeter: Learning matters (2009) 
[13] Christodoulou, N.: The impact of guided reflective practice on the teaching of English as a foreign language in higher education in Cyprus. An unpublished thesis. University of Nottingham (2013) Available at: http://eprints.nottingham.ac.uk/13635/1/ThesisNiki_Christodoulou.pdf

[14] Craft, A.: 'Little c creativity'. In A. Craft, B. Jeffrey, and M. Leibling (Eds.), Creativity in education. London: Continuum (2001)

[15] Creswell, J. W.: Educational research: Planning, conducting, and evaluating quantitaive and qualitative research. New Jersey: Prentice Hall (2007)

[16] Csikszentmihalyi, M.: Creativity: Flow and the psychology of discovery and invention. New York: Harper Collins (1996)

[17] Dewey, John.: How we think: A restatement of the relation of reflective thinking to the educative process. Boston: D.C. Heath and Company (1933)

[18] Dianawati, H. and Mulyono, H.: Facilitating students' creativity in an EFL writing classroom: Voices from the field. Argentinian Journal of Applied Linguistics-AJAL, Vol. 4, pp. 39-47 (2016) Available online at: http://www.faapi.org.ar/ajal/issues/402/MulyonoAJALVol4(2).pdf

[19] Elo S. and Kyngas, H.: The qualitative content analysis process. Journal of Advanced Nursing Vol. 62, pp. 107-115 (2008) doi: 10.1111/j.1365-2648.2007.04569.x.

[20] Farrell, T. S. C.: Reflective language teaching: From research to practice. London: Continuum (2007)

[21] Farrell, S. C. F.: Reflective Practice in the Professional Development of Teachers of Adult English Language Learners (2011)

[22] Farrell, T. S. C.: Reflective practice in ESL teacher development group: From practices to principles. New York: Palgrave Macmillan (2013)

[23] Flick, U.: An introduction to Qualitative research ( $5^{\text {th }}$ ed.). London: SAGE (2014)

[24] Freire, P.: Pedagogy of the oppressed. New York: Penguin Books Ltd (1972)

[25] Ghaye, T.: Teaching and learning through reflective practice: A practical guide for positive action. ( $2^{\text {nd }}$ Ed.). London: Routledge (2011)

[26] Giorgi, A., Giorgi, B. and Morley, J.: The Descriptive Phenomenological Psychological Method. In C. Willig and W. S. Rogers (Eds.). The SAGE Handbook of Qualitative Research in Psychology ( $2^{\text {nd }}$ ed.). London: SAGE Publications (2017)

[27] Hall, G.: Exploring English language teaching: Language in action (2 $2^{\text {nd }}$ Ed.) London: Taylor \& Francis Ltd (2018)

[28] Jones, R. H.: Creativity and discourse. World Englishes, Vol. 29, pp. 467-480 (2010)

[29] Joubert, M. M.: The art of creative teaching: NACCCE and beyond. In A. Craft, B. Jeffrey, and M. Leibling (eds.), Creativity in education. London: Continuum (2001)

[30] Kiely, R.: Integrating reflection in teacher education: Guidelines for Practice. ESL Practitioner, Vol. 2, pp. 1-32 (2013)

[31] Kiely, R., Davis, M. , Carter, G. and Nye, C.: The craft of the experienced language teacher. Voices Issue 205. Kent: IATEFL (2008)

[32] Kiely, R., and Davis, M.: From transmission to transformation: Teacher learning in English for speakers of other languages, Vol. 14, pp. 277-295 (2010)

[33] Krippendorff, K.: Measuring the Reliability of Qualitative Text Analysis Data. Quality and Quantity, Vol. 38, pp. 787-800 (2004) https://doi.org/10.1007/s11135-004-8107-7

[34] Kumaravadivelu, B.: The Postmethod Condition: (E)merging Strategies for Second/Foreign Language Teaching, TESOL Quarterly, Vol. 28, pp. 27-48 (1994)

[35] Kumaravadivelu, B.: Toward a Post-method Pedagogy. TESOL QUARTERLY, Vol. 35, pp. 537-560 (2001)

[36] Kumaravadivelu, B.: Method, antimethod, post-method. IATEFL York Conference Selections. York: IATEFL: Opening Plenary, IATEFL $36^{\text {th }}$ International Annual Conference (2002)

[37] Kumaravadivelu, B.: Critical language pedagogy: A postmethod perspective on English language teaching. World Englishes, Vol. 22, pp. 539-550 (2003a)

[38] Kumaravadivelu, B.: Beyond Methods: Macrostrategies for language teaching. New Haven, CT. Yale University Press (2003b) 
[39] Kumaravadivelu, B.: Understanding language teaching: From method to postmethod (ed.). New York: Routledge (2005)

[40] Kumaravadivelu, B.: TESOL methods: Changing tracks, challenging trends. TESOL Quarterly, Vol. 40, pp. 59-81 (2006)

[41] Larsen-Freeman, D., and Long, M. H.: An introduction to second language acquisition research. London: Longman (1991)

[42] Lave, J. and Wenger, E.: Situated Learning. Legitimate peripheral participation. New York: Cambridge University Press (1991)

[43] Loveless, A.: Thinking about creativity: Developing ideas, making things happen. In A. Wilson (ed.), Creativity in primary education ( $2^{\text {nd }}$ ed.). Exeter: Learning Matters Ltd (2007)

[44] Lubis, A. H.: Reflective teaching toward EFL teachers' professional autonomy: Revisiting its development in Indonesia. International Journal of Education, Vol. 11, pp. 35-49 (2018) doi: http://dx.doi.org/10.17509/ije.v11i1.9400

[45] Maley, A. and Bolitho, R.: Creativity: Key concepts in ELT. ELT Journal, Vol. 69, pp. 434-436 (2015) Available at http://eltj.oxfordjournals.org/

[46] Marshall, C., and Rossman, G. B.: Designing Qualitative Research. Newbury Park, CA: SAGE (1999)

[47] Maybin, J. and Swann, J.: Everyday creativity in language: Textuality, contextuality and critique. Applied Linguistics, Vol. 28, pp. 497-517 (2007) Available at: https://scholar.google.co.uk/

[48] Mayring, P.: Qualitative content analysis. In U. Flick, E. von Kardoff and I. Steinke (eds.), A companion to qualitative research. London: Sage (2004)

[49] McCallum, A. F.: Teachers' Constructions of Creativity in Secondary English: Who Gets to Be Creative in Class? An unpublished thesis. London Metropolitan University (2018) Available online at:

http://repository.londonmet.ac.uk/2761/1/McCallum\%2CAndrew_Thesis.pdf

[50] Pennycook, A.: "The rotation gets thick. The constraints get thin": Creativity, contextualization, and difference. Applied linguistics, Vol. 28, pp. 579-596 (2007)

[51] Prabhu, N. S.: There is no best method-Why? TESOL Quarterly, Vol. 24, pp. 161-176 (1990)

[52] Richards, J. C.: Creativity in language teaching. Iranian Journal of Language Teaching Research, Vol. 1, pp. 19-43 (2013) Available at: www.urmia.ac.ir/ijltr

[53] Richards, J. C. and Cotterall, S.: Exploring Creativity in Language Teaching. In Jones, R. H. And Richards, J. C. (eds.), Creativity in Language Teaching: Perspectives from Research and Practice, pp. 97-113 New York: Routledge (2016)

[54] Robson, C.: Real World Research. (3rd ed.). Sussex: John Wiley \& Sons Ltd (2002)

[55] Salmani-Nodoushan, M. A.: Reflective teaching in EFL classes: an overview. i-manager's Journal on School Educational Technology, Vol. 6 (2011) Retrieved from: https://files.eric.ed.gov/fulltext/EJ1102745.pdf

[56] Sawyer, R K.: Creative Teaching: Collaborative Discussion as Disciplined Improvisation. Educational Researcher, Vol. 33, pp. 12-20 (2004)

[57] Savin-Baden, M., and Major, C. H.: Qualitative research: The essential guide to theory and practice. London: Routledge (2013)

[58] Schon, D.: The reflective practitioner: How professional think in action. New York: Basic Books (1983)

[59] Schon, D.: Educating the reflective practitioner. San Francisco: Jossey Bass (1987)

[60] Schreier, M.: Qualitative content analysis in practice. London: Sage Publications Ltd (2012)

[61] Sellars, M.: Reflective practice for teachers. London: SAGE Publication Ltd (2014)

[62] Shepherd, S.: Using authentic materials (2019) Available online at: https://www.teachingenglish.org.uk/article/using-authentic-materials

[63] Springer, K.: Educational research: A contextual approach. New Jersey: Wiley John Wiley \& Sons, Inc (2010)

[64] Starbuck, D.: Creative teaching: Learning with style ( $2^{\text {nd }}$ ed.). London: Continuum (2012)

[65] Stern, H. H.: Fundamental concepts of language teaching. Oxford: Oxford University Press (1983) 
[66] Ushida, E.: The role of students' attitudes and motivation in second language learning in online language courses. CALICO Journal, Vol. 23, pp. 49-78 (2005)

[67] Thiel, T.: Reflections on critical incidents. Prospect, Vol. 14, pp. 44-52 (1999)

[68] Tin, T., Manara, C. and Ragawanti, D.: "Views on creativity from an Indonesian perspective". ELT Journal, Vol. 64, pp. 75-84 (2010)

[69] Vaismoradi, M. et al.: Content analysis and thematic analysis: Implications for conducting a qualitative descriptive study. Nursing \& Health Sciences, Vol. 5, pp. 398-405 (2013)

[70] Walsh, S. and Mann, S.: Doing reflective practice: A data-led way forward. ELT Journal, Vol. 69, pp. 351-362 (2015) doi: https://doi.org/10.1093/elt/ccv018

[71] York-Barr, J., et al.: Reflective practice to improve schools: An action guide for educators. ( $2^{\text {nd }}$ ed.). California: CORWIN PRESS - A SAGE Publications Company (2006) 